\title{
Estrogen receptor (ESR) 2 partially offsets the absence of ESR1 in gonadotropes of pituitary-specific Esr1 knockout female mice
}

\author{
José E Sánchez-Criado ${ }^{1,3}$, Kourtney Trudgen ${ }^{3}$, Yolanda Millán², Alfonso Blanco², \\ José Monterde ${ }^{2}$, José C Garrido-Gracia ${ }^{1}$, Ana Gordon ${ }^{1}$, Rafaela Aguilar ${ }^{1}$, \\ Juana Martín de las Mulas ${ }^{2}$ and CheMyong $\mathrm{Ko}^{3}$
}

Departments of ${ }^{1}$ Cell Biology, Physiology and Immunology and ${ }^{2}$ Comparative Pathology, University of Córdoba, 14004 Córdoba, Spain and ${ }^{3}$ Center of Excellence in Reproductive Sciences, University of Kentucky, Lexington, Kentucky 40536, USA

Correspondence should be addressed to J E Sánchez-Criado who is now at Sección de Fisiología, Facultad de Medicina, Universidad de Córdoba, Avenida Menendez Pidal s/n, 14004 Córdoba, Spain; Email: fi1sacrj@uco.es

J E Sánchez-Criado and K Trudgen contributed equally to this work

\begin{abstract}
Estrogen receptor 1 and 2 (ESR1 and 2) mediate estrogen (E) action on gonadotrope function. While much is known about the effects of ESR1 on the gonadotrope, there is still some controversy regarding the effects of ESR2. To investigate the role of ESR2 in the gonadotrope, 45-day-old female mice of two different genotypes were used: wild type (WT) and pituitary (gonadotropes and thyrotropes)-specific Esr1 knockout (KO). All mice were ovariectomized (OVX) and 15 days later injected over 3 days with $2.5 \mu \mathrm{g} 17 \beta$-estradiol ( $E_{2}$ ), $0.2 \mathrm{mg}$ of the selective ESR1 or 2 agonists, propylpyrazole triol and diarylpropionitrile, respectively, or $0.1 \mathrm{ml}$ oil. The day after treatment, anterior pituitary glands were dissected out for evaluation of gonadotrope ultrastructural morphology and pituitary immunohistochemical expression of progesterone receptor $(\operatorname{Pgr}(\mathrm{Pr}))$. Blood was collected and serum LH levels were assessed. Activation of ESR1 in WT mice resulted in the following: i) uterine ballooning and vaginal cornification, ii) negative feedback on LH secretion, iii) increased number of homogeneous (functional) gonadotropes, and iv) pituitary Pgr expression (35.9 $\pm \mathbf{2 . 0} \%$ of pituitary cells). Activation of ESR1 in KO mice induced normal uterine, vaginal, and $\mathrm{LH}$ secretion responses, but failed to increase the number of functional gonadotropes, and induced significantly lower Pgr expression (21.0 $\pm 3.0 \%$ of pituitary cells) than in WT mice. Whilst activation of ESR2 had no significant effects in WT mice, it doubled the number of functional gonadotropes exhibited by KO mice injected with oil. It is concluded that $E_{2}$ exerted its action in KO mouse gonadotropes via ESR2.
\end{abstract}

Reproduction (2012) $\mathbf{1 4 3} 549-558$

\section{Introduction}

Gonadotrope function in rodents and other species (Schwartz 2000) is dependent on the activation of estrogen receptors (ESRs) by ovarian-derived estrogen (E; Fink 1988). In its negative feedback mode, E maintains $\mathrm{LH}$ secretion at low levels during estrus, metestrus, diestrus, and proestrus morning in rats and mice (Fink 1988). This action is evident in the decreasing effect of exogenous $\mathrm{E}$ on serum LH levels in ovariectomized (OVX) animals. However, the relative contribution of the pituitary to the inhibitory feedback by gonadotrope ESR remains unclear (Fink 1988, Messinis 2006).

In its positive feedback mode, E acts on the hypothalamus-pituitary axis (Goodman \& Knobil 1981, Parker 1995), triggering a surge of the hypothalamic decapeptide GNRH1 and greatly augmenting pituitary responsiveness to GNRH1 (Fink 1988, 2000). At the pituitary level, the effects of $E$ on the gonadotrope are exerted through activation of the complete gonadotrope ESR orchestra (Alonso et al. 2006). Rat and mouse gonadotropes express both ESR1 and 2 isoforms (Wilson et al. 1998, Sánchez-Criado et al. 2005, Gieske et al. 2008). The actions of ESR1 are much better known (Parker 1995) than those of ESR2, which remain elusive (Pettersson \& Gustafsson 2001, Imamov et al. 2005, Koehler et al. 2005, Sugiyama et al. 2010). The role played by each ESR isoform in the gonadotrope is currently being studied, in vivo and in vitro, in OVX rats injected with the selective ESR1 and 2 agonists, propylpyrazole triol (PPT) and diarylpropionitrile (DPN), respectively (Sánchez-Criado et al. 2004, Garrido-Gracia et al. 2007, 2008), and in global or ESR isoform-specific knockout (KO) mice (Dupont et al. 2000, Hewitt \& Korach 2003, Gieske et al. 2008, Singh et al. 2009, Kim et al. 2011). 
In the rat, E withdrawal by OVX induces gonadotrope hypertrophy, disorganization of membrane-enclosed intracellular organelles, lack of expression of gonadotrope progesterone receptor $(\operatorname{Pgr}(P r))$, and elevated serum LH levels (Sánchez-Criado et al. 2004, 2005), and a 3-day E treatment reverses the effects of OVX resulting in proestrus-like rats (Legan \& Tsai 2003). Both in rats (Sánchez-Criado et al. 2005) and in mice (Turgeon \& Waring 1994), the absence of ligand-dependent or -independent activation of gonadotrope E-dependent PGR results in the reduction of GNRH1 self-priming and $\mathrm{LH}$ surge. Activation of ESR2 by DPN treatment in OVX rats has similar but milder effects to activation of ESR1 with PPT, including i) shrinkage of hypertrophied gonadotropes, ii) reorganization of disrupted intracellular organelle morphology, and iii) induction of $\mathrm{Pgr}$ expression in the gonadotrope without eliciting GNRH1 self-priming. The only exception is the lack of effect of ESR2 activation on LH secretion (Sánchez-Criado et al. 2004). However, main weakness of these results is that PPT and DPN are not totally selective (Sun et al. 1999, Stauffer et al. 2000, Meyers et al. 2001, Harris et al. 2002), and OVX rat gonadotropes express both ESR1 and 2 (Sánchez-Criado et al. 2005). Pituitary-specific Esr KO mice appear to be an excellent model for determining the effects of pituitary ESR1 or ESR2 activation in the complete absence of ESR2 or ESR1, respectively.

This study investigated the effects of specific ESR1 and 2 activation on gonadotrope ultrastructural morphology and pituitary immunohistochemical (IHC) Pgr expression in OVX wild-type (WT) and pituitary (gonadotrope and thyrotrope)-specific Esr1 KO mice (Gieske et al. 2008). The effects of ESR agonists (17 $\beta$-estradiol $\left(E_{2}\right), P P T$, and DPN) on uterus and vagina and on $\mathrm{LH}$ release were also evaluated.

\section{Results}

\section{Vaginal smear cytology and uterine ballooning in OVX WT and KO mice}

Oil-injected female OVX mice of both WT and KO genotypes displayed absence of uterine ballooning, and vaginal smears exhibited infiltration mainly by leukocytes. Both WT and KO OVX females injected with $E_{2}$ and PPT displayed intense uterine ballooning and nucleated and/or cornified epithelial cells on vaginal smears. Finally, OVX WT and KO females injected with DPN displayed neither uterine ballooning nor nucleated or cornified cells on vaginal smears.

\section{Pituitary Esr2 expression in OVX WT and OVX KO mice}

Gonadotropes, identified by IHC expression of $L h b$ $(\beta L H)$ (reddish cytoplasms), expressed Esr2 (orange nuclei) in both OVX WT (Fig. 1A) and KO (Fig. 1B) genotypes.
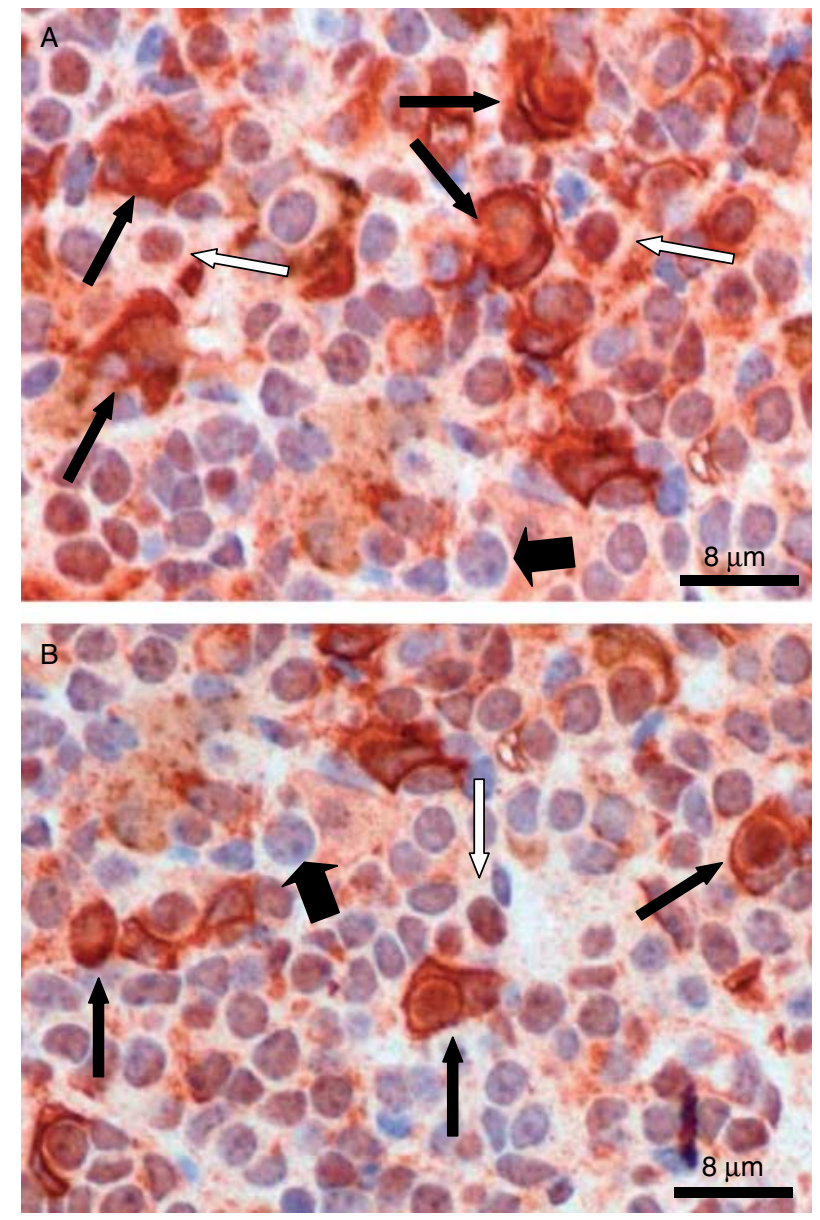

Figure 1 Co-localization of ESR2 in gonadotropes of WT (A) and KO (B) oil-injected OVX mice. Nuclear expression of Esr2 (orange color) is seen in gonadotropes identified by cytoplasmic expression of $L h b$ (reddish color, thin black arrows in A and B). Nuclear expression of Esr2 is also seen in pituitary cells other than gonadotropes (white arrows). Negative nuclei are also visible (thick arrows). Double consecutive ABC methods. See Materials and Methods section for technical details.

\section{Identification, number, and size of gonadotropes in $O V X W T$ and KO mice: effects of ER ligand treatments}

Gonadotropes were identified ultrastructurally as described in Materials and Methods section (Fig. 2). Gonadotropes of OVX WT and KO mice accounted for $11.2 \pm 0.3$ and $10.1 \pm 0.3 \%$, respectively, of the total number of pituitary cells; the mean diameter of gonadotropes in OVX WT and KO mice was $11.0 \pm 0.9$ and $10.1 \pm 0.5 \mu \mathrm{m}$, respectively. No differences in the number and size of gonadotropes were found between OVX WT and KO mice or among the different ESR ligand treatments (results not shown).

\section{Ultrastructural features of gonadotropes in OVX WT and OVX KO mice: effects of ESR ligands}

Ultrastructurally, two different types of gonadotropes were distinguished in OVX WT and KO mice: 


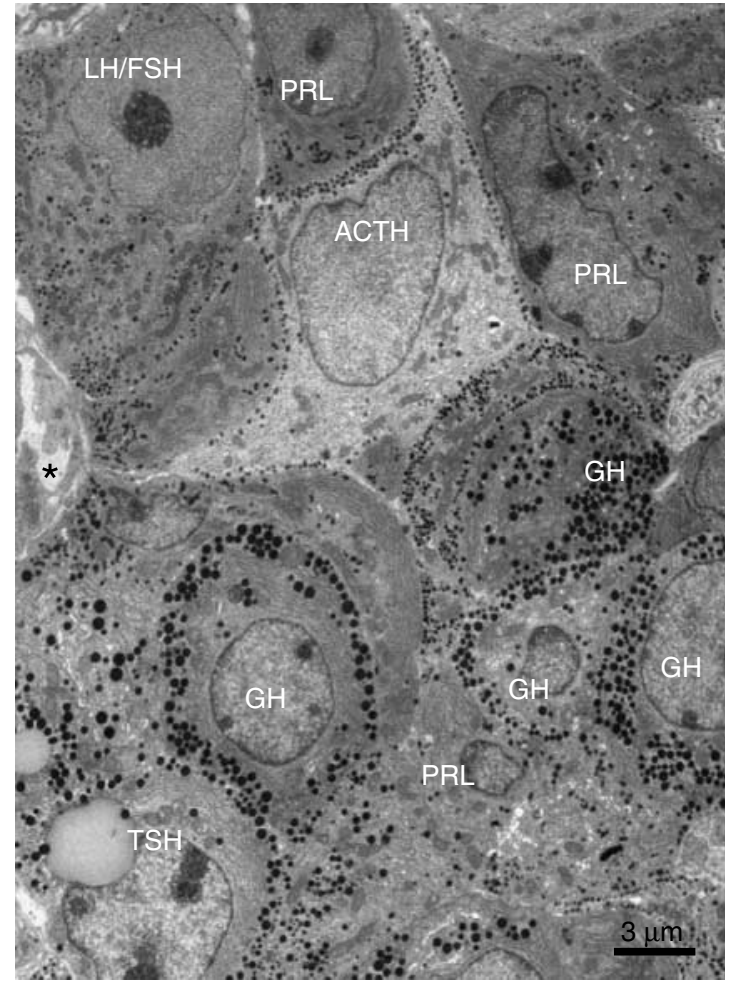

Figure 2 Anterior pituitary cell types identified by key ultrastructural features. A gonadotrope ( $\mathrm{LH} / \mathrm{FSH})$ with rounded, eccentric nuclei and homogeneous, moderately electron-dense cytoplasm containing scarce, rounded secretory granules of slightly varying size is visible close to a blood capillary (asterisk). Lactotropes (PRL) had rounded to elongated nuclei and dark cytoplasm; secretory granules varied considerably in size and shape. The single corticotrope (ACTH) observed displayed the lowest nuclear and cytoplasmic electron density. Somatotropes $(\mathrm{GH})$, the most numerous cells, had large, rounded secretory granules of fairly homogeneous size, located peripherally in the cytoplasm. Finally, the thyrotrope (TSH) had rounded nuclei with moderately electron-dense cytoplasm and scarce secretory granules of homogeneous size. See Materials and Methods section for additional details. Pituitary section from an OVX WT mouse injected with oil.

homogeneous $(\mathrm{H})$ and vesiculated/degenerated $(\mathrm{V} / \mathrm{D})$ (Fig. 3). H gonadotropes (Fig. 3A) had rounded, eccentric euchromatic nuclei with one or two nucleoli. The moderately electron-dense cytoplasm was homogeneous and contained abundant, slightly dilated RER cisternae with low density, uniform content, welldeveloped Golgi complex(es), and abundant dense matrix mitochondria. Scarce rounded, electron-dense secretion granules varying in size from 200 to $400 \mathrm{~nm}$ were observed in the proximity of the cytoplasmic membrane, either singly or in small clusters. The most striking feature of V/D gonadotropes (Fig. $3 \mathrm{~B}$ and C) was the disorganization of membrane-enclosed intracellular organelles, including regular or irregular dilatation of empty RER cisternae, giving the cytoplasm a vesiculated or vacuolated appearance; Golgi complex and secretory granules were either small or absent. Varying number of mitochondria was observed. Some V/D gonadotropes (Fig. 3C) displayed irregular nuclei with highly condensed chromatin and a dilated envelope.

Although in different proportions, all groups of OVX WT and KO mice exhibited both types of gonadotropes
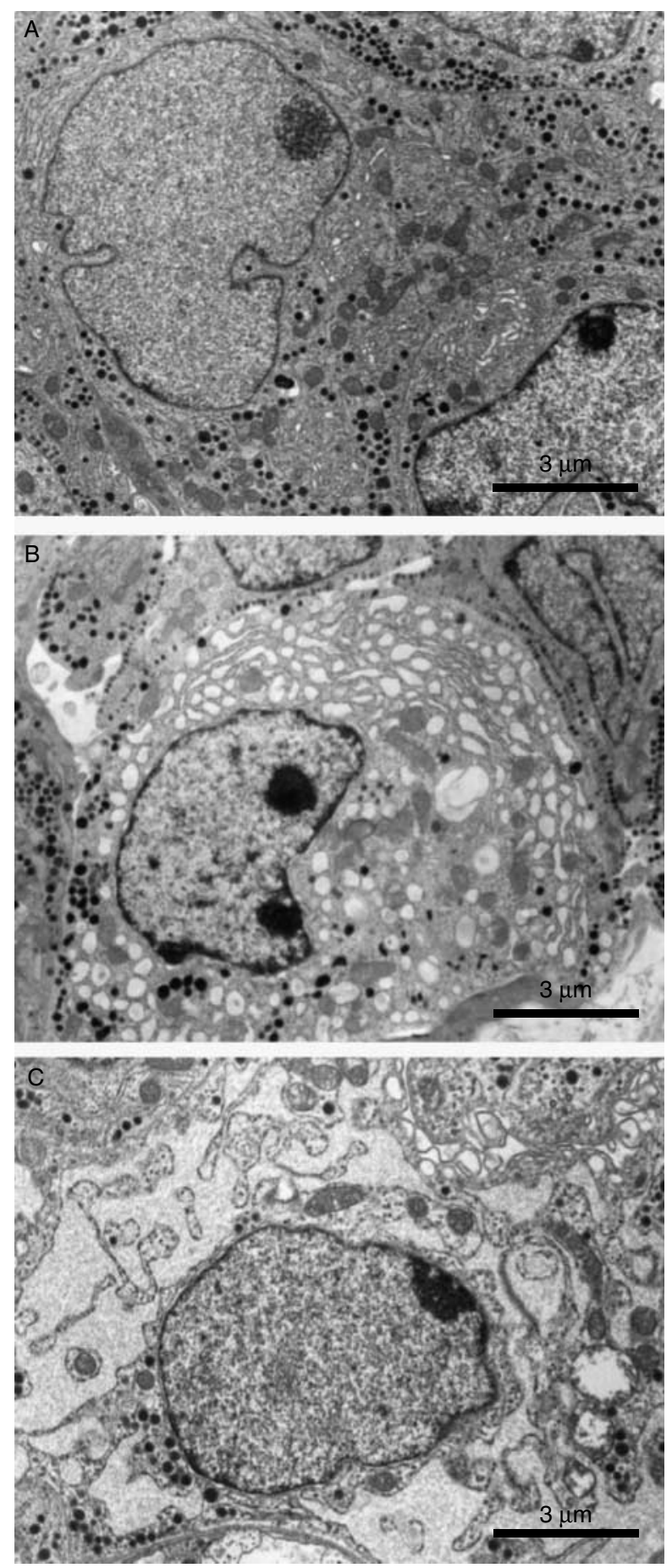

Figure 3 Representative micrographs of gonadotrope subtypes: homogeneous (A), vesiculated (B), and degenerated/vacuolated (C) found in OVX WT and KO mice injected with oil, $E_{2}$, PPT, or DPN. See Fig. 2 for detailed description of gonadotropes. 


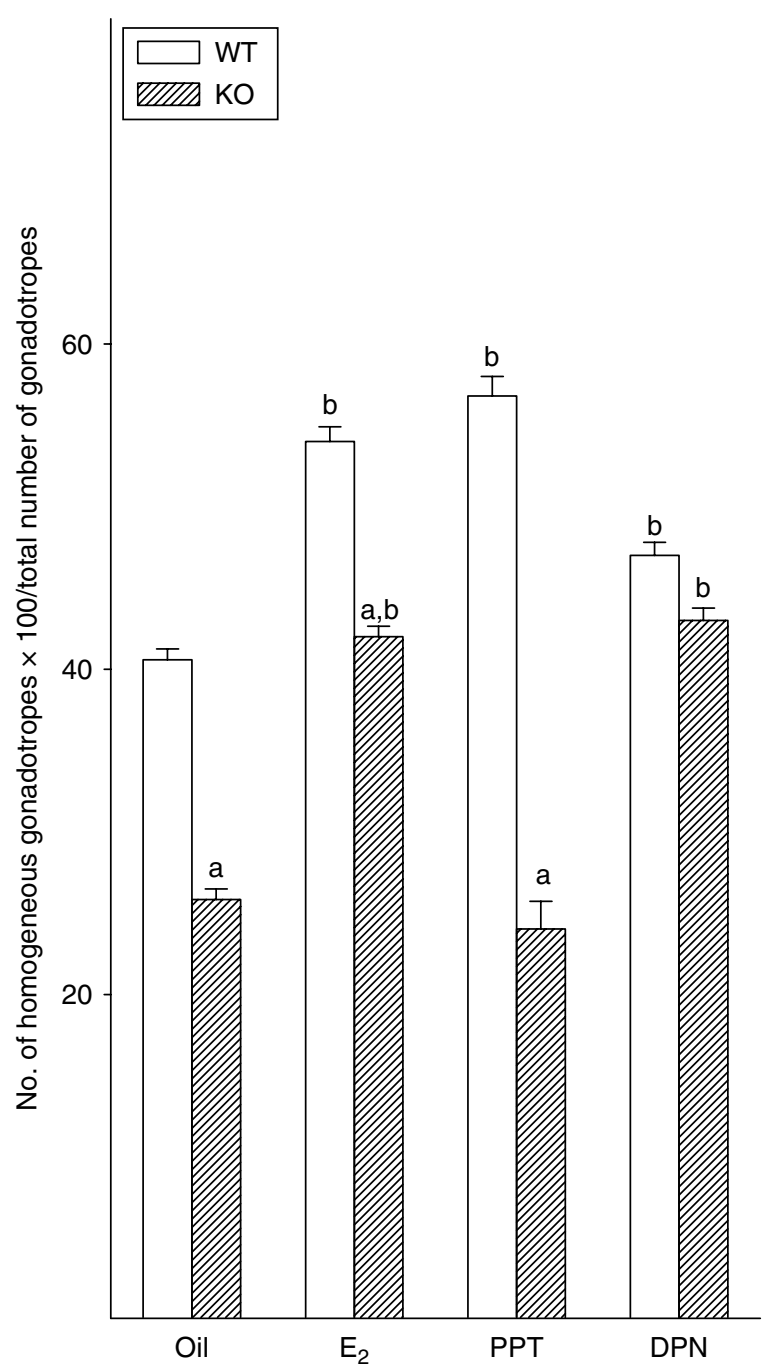

Figure 4 Percentage of homogeneous gonadotropes in OVX WT and KO mice injected with oil, $E_{2}$, PPT, or DPN (see the legend of Fig. 2 and Materials and Methods section for morphological and treatment details). ${ }^{a} P<0.05$ vs corresponding OVX WT treatment group; ${ }^{\mathrm{b}} P<0.05$ vs corresponding genotype oil-injected mice. ANOVA followed by Student-Newman-Keuls multiple range test.

(Fig. 4). OVX WT mice injected with oil vehicle exhibited $40.6 \pm 0.7 \%$ of $\mathrm{H}$ gonadotropes compared with $25.9 \pm 0.6 \%$ in OVX KO mice $(P<0.05$; Fig. 4). Differences were also found in the effects of ESR ligands. Treatment of OVX WT mice with $\mathrm{E}_{2}$ and PPT increased $(P<0.05)$ the percentage of $\mathrm{H}$ gonadotropes to 54.0 \pm 0.9 and $56.8 \pm 1.2 \%$, respectively, and, accordingly, decreased that of $\mathrm{V} / \mathrm{D}$ gonadotropes. DPN treatment also prompted a less marked increase $(P<0.05)$ in the percentage of $\mathrm{H}$ gonadotropes to $47.0 \pm 0.8 \%$. In OVX $\mathrm{KO}$ mice, $\mathrm{E}_{2}$ and DPN had similar effects on gonadotrope morphology; the percentage of $\mathrm{H}$ gonadotropes increased significantly to $42.0 \pm 0.7$ and $43.0 \pm 0.8 \%$, respectively $(P<0.05)$. By contrast, PPT exerted no effect compared with oil treatment in OVX KO mice.

\section{Pituitary Pgr expression in OVX WT and KO mice: effects of ESR ligand treatments}

Pituitaries from OVX mice of both genotypes injected with oil vehicle did not express PGR (Figs 5A and 6). Treatment with $\mathrm{E}_{2}$ or the selective ESR1 agonist PPT (Figs $5 \mathrm{~B}, \mathrm{C}$ and 6), but not the selective ESR2 agonist DPN, induced Pgr expression in both OVX genotypes (Fig. 6). However, the percentages of PGR-positive cells in the pituitaries of OVX WT mice treated with $E_{2}$ and PPT were $38.4 \pm 2.6$ and $33.3 \pm 2.2 \%$, respectively, while
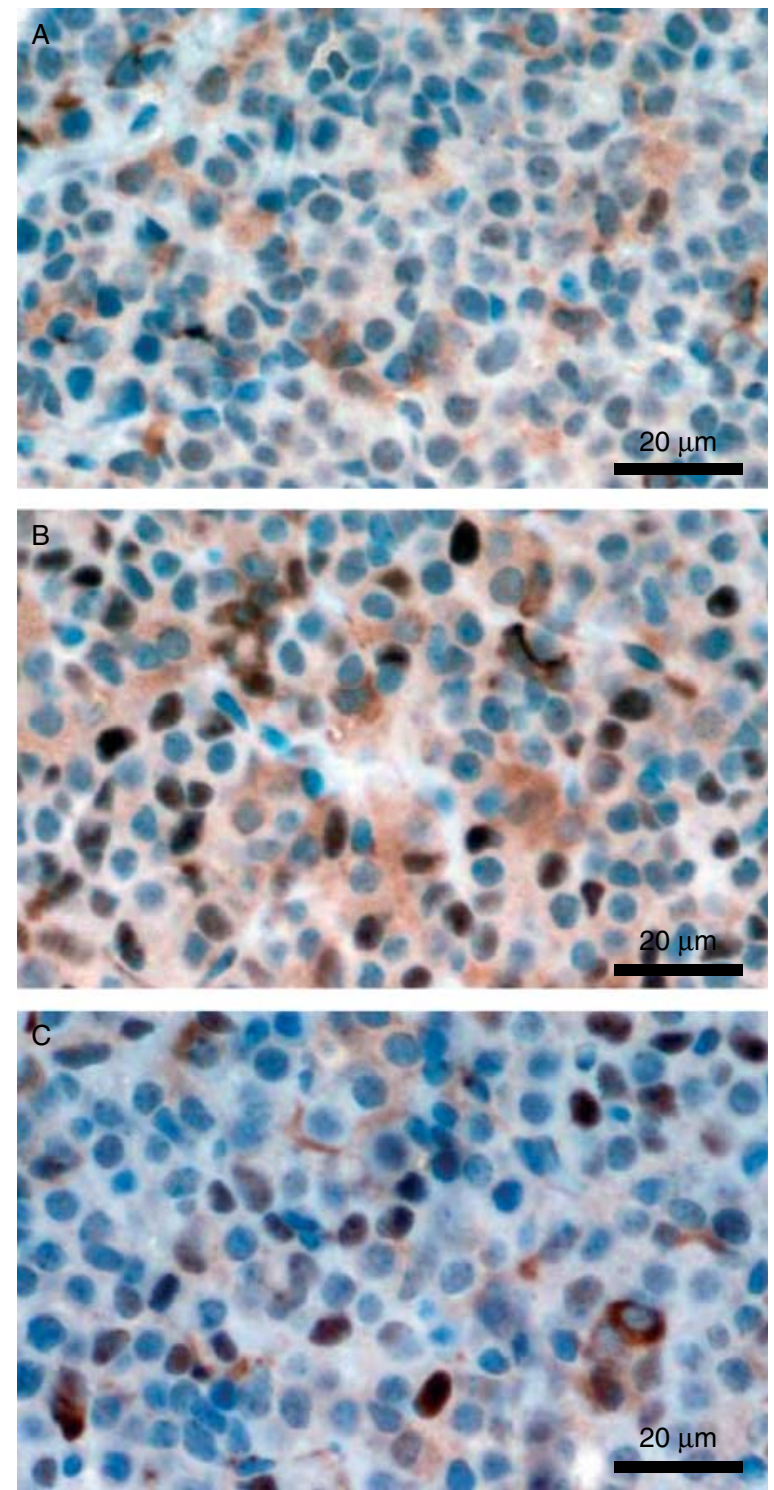

Figure 5 PGR immunohistochemistry of the pituitary of OVX WT and KO mice injected with oil, E2, PPT, or DPN (see the Materials and Methods section for details of treatments). (A) Representative examples of the lack of Pgr expression in WT+oil, WT+DPN, $\mathrm{KO}+$ oil, or $\mathrm{KO}+\mathrm{DPN}$ OVX mice. (B) Pgr expression in the pituitaries of WT + PPT or $+E_{2}$ OVX mice. (C) Pgr expression in the pituitaries of $\mathrm{KO}+\mathrm{PPT}$ or $+\mathrm{E}_{2}$ OVX mice. 


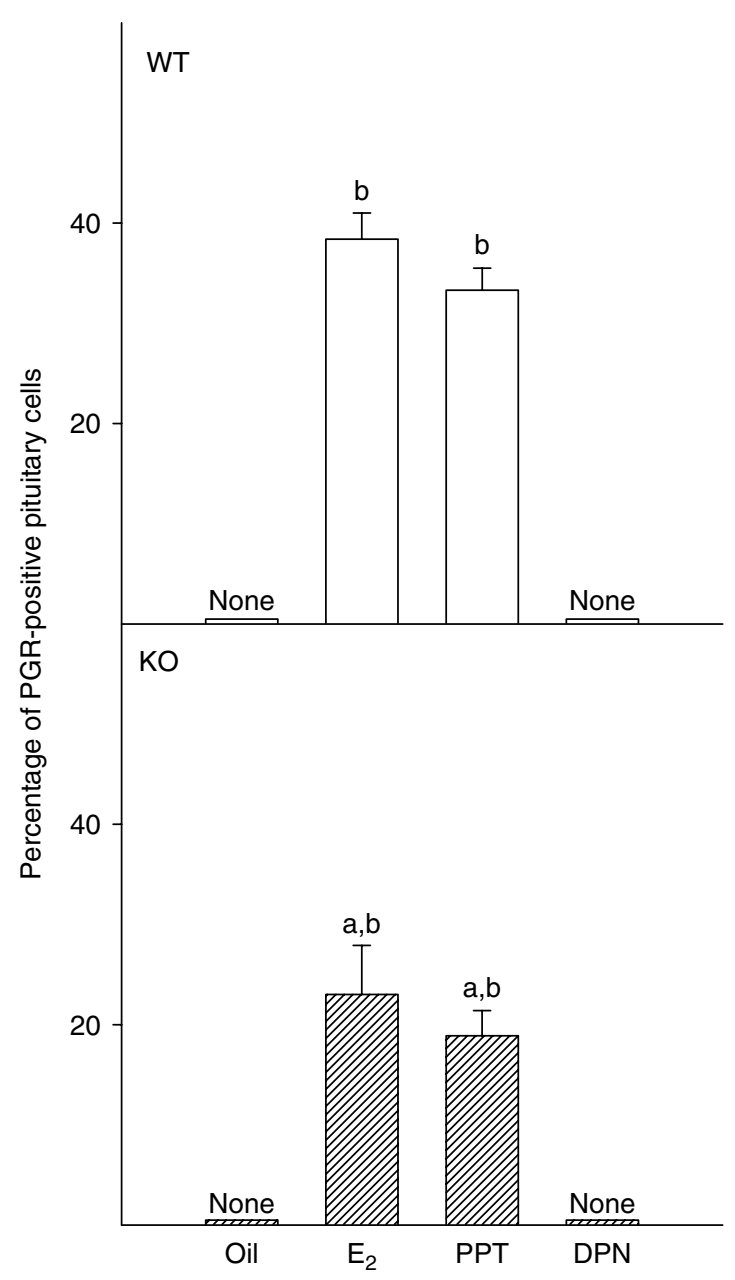

Figure 6 Percentage of positive PGR pituitary cells in OVX WT and KO mice injected with oil, $E_{2}$, PPT, or DPN (see Materials and Methods section for details of treatments). ${ }^{\mathrm{a}} P<0.05$ vs corresponding OVX WT treatment groups; ${ }^{b} P<0.05$ vs corresponding genotype oil-injected mice. ANOVA followed by Student-Newman-Keuls multiple range test.

percentages were significantly lower $(23.0 \pm 4.9$ and $18.9 \pm 2.5 \%$, respectively) in OVX KO mice (Fig. 6).

\section{Effects of ESR ligands on serum $\mathrm{LH}$ concentrations in OVX WT and KO mice}

In comparison with oil-injected OVX WT and $\mathrm{KO}$ mice, treatment with DPN had no effect on serum LH concentrations in OVX mice of either OVX genotype (Fig. 7). By contrast, treatment with $\mathrm{E}_{2}$ and PPT significantly decreased serum $\mathrm{LH}$ concentrations in both genotypes. No differences in serum LH levels were found between WT and KO OVX mice (Fig. 7) for any of the treatments.

\section{Discussion}

The results indicated that selective activation of ESR2 in OVX KO mice increased the number of homogeneous gonadotropes of normal appearance, but had no effect on Pgr expression, LH secretion, or peripheral target E-dependent tissues. In addition, the results indicated similar Esr2 expression in gonadotropes of both OVX KO and WT mice. Other authors report that only gonadotropes and thyrotropes from pituitaries of OVX KO mice lack Esr1 (Gieske et al. 2008, Singh et al. 2009). Moreover, the selective lack of Esr1 expression in gonadotropes was confirmed in the present study by: i) the lack of effect of PPT on the number of homogeneous gonadotropes in OVX KO mice, ii) the similar response, in both mouse genotypes, of uterus and vagina to $E_{2}$ and PPT but not to DPN treatment (present results, Harris et al. 2002, Frasor et al. 2003, Hewitt \& Korach 2003), iii) the negative feedback of ESR1 activation on LH secretion in both OVX WT and KO mice, and iv) significantly $(P<0.05)$ lower expression of $P g r$ in OVX KO than in OVX WT mice. Taken in conjunction, these

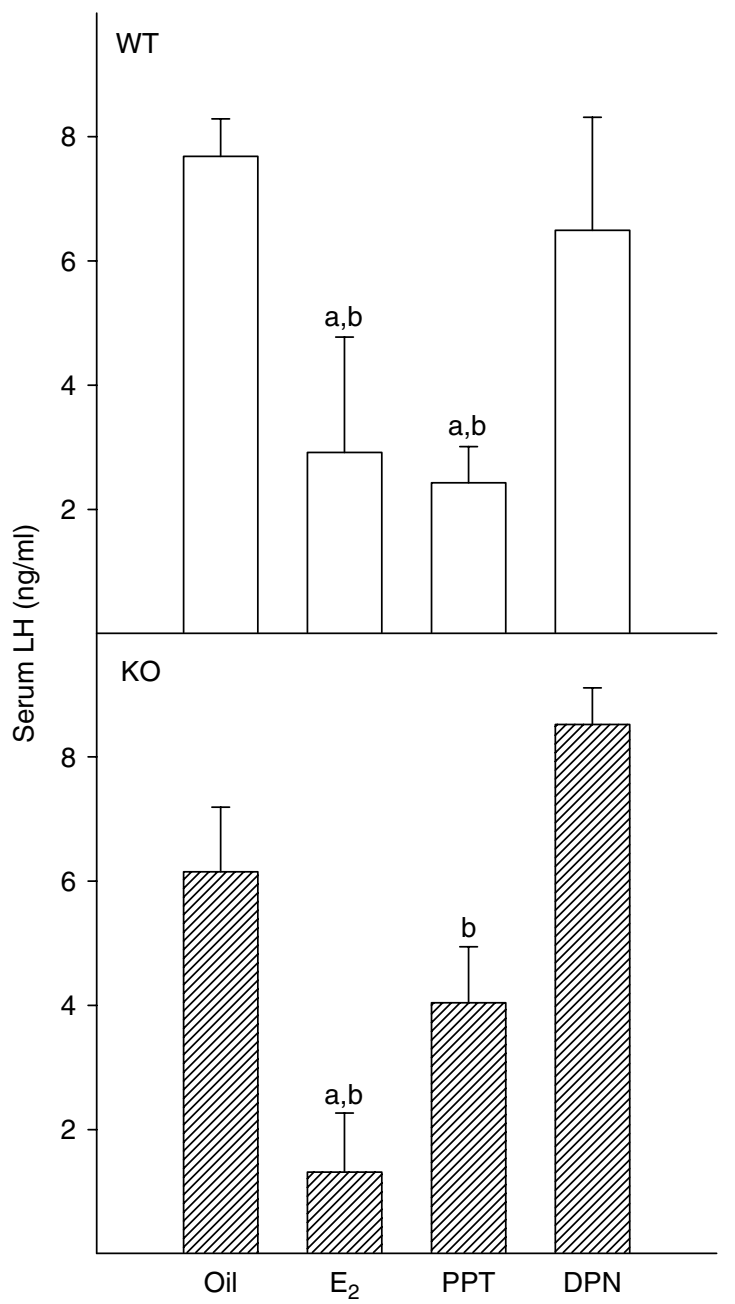

Figure 7 Serum LH concentrations $(\mathrm{ng} / \mathrm{ml})$ in OVX WT and KO mice injected with oil, E2, PPT, or DPN (see Materials and Methods section for details of treatment). No differences were found between $\mathrm{LH}$ levels in OVX WT and KO mice. ${ }^{\mathrm{a}} P<0.05$ vs corresponding genotype oil-injected mice; ${ }^{b} P<0.05$ vs DPN-injected OVX KO mice. ANOVA followed by the Student-Newman-Keuls multiple range test. 
findings confirmed, though only in part, the adequacy of the model used to study the effects of specific activation of ESR2 on mouse gonadotropes. Also, in contrast with our original hypothesis, results indicated the existence of striking pituitary differences between rats and mice.

The present findings contrast with those obtained by the authors in rats, in which ESR2 replaced most ESR1 action including shrinkage of OVX-induced hypertrophy of gonadotropes, reorganization of membrane-enclosed intracellular organelles, and gonadotrope Pgr expression (Sánchez-Criado et al. 2006). Gonadotrope size in OVX $\mathrm{KO}$ mice was similar to that of OVX WT mice both in controls and in ESR ligand-treated animals. In the rat, a time-dependent hypertrophy takes place after OVX even to the extent of forming signet-ring cells from 35 days onward (Garner \& Blake 1981), reversible after ESR1 activation (Gordon et al. 2009). No signet-ring gonadotropes were observed at the time of the study in the pituitaries of either OVX WT or KO mice lacking ESR1 activity. In addition, $E_{2}$ and PPT treatment of OVX WT mice did not reduce the size of gonadotropes, as occurs in the rat (Sánchez-Criado et al. 2006). These findings suggest that OVX-induced $\mathrm{E}$ withdrawal was not followed, under the current conditions, by gonadotrope hypertrophy.

Differences in gonadotrope morphology were observed between OVX KO and WT mice; the former had significantly fewer $\mathrm{H}$ gonadotropes than the latter. These are considered to be the functional gonadotropes found in proestrus (Garner \& Blake 1981, SánchezCriado et al. 2005). Moreover, activation of ESR2 with either $\mathrm{E}_{2}$ or DPN increased the number of $\mathrm{H}$ gonadotropes in OVX WT and KO mice while activation of ESR1 with PPT increased the number of $\mathrm{H}$ gonadotropes only in OVX WT mice exclusively. The finding that pituitaries of OVX KO mice still exhibited $\mathrm{H}$ gonadotropes, together with the absence of gonadotrope hypertrophy, may suggest that endogenous $\mathrm{E}$ played a role in OVX KO mice gonadotrope biology through ESR2 activation by inducing the reorganization of membrane-enclosed intracellular organelles, mostly RER cisternae and Golgi complexes, thus increasing the pool of homogeneous gonadotropes at the expense of vesiculated/ degenerated gonadotropes. This gonadotrope recruitment would then be capable of response to GNRH1 stimulation under the E-positive feedback mode (Smith et al. 1984). In the rat, OVX-induced disorganization of membrane-enclosed intracellular organelles is also reversed by DPN treatment in the absence of ESR1 activation (Sánchez-Criado et al. 2006, Garrido-Gracia et al. 2008). However, although these effects on gonadotrope morphology were also seen in OVX WT and $\mathrm{KO}$ mice, the absence of effect of OVX on gonadotrope size at the time of the study suggests that gonadotrope morphology in the mouse is not under such a strong estrogenic control as it is in the rat.
The present results also showed that pituitary cells did not express PGR in the absence of ESR1 activation (OVX WT and KO mice whether injected with oil or DPN). This confirms the strong ESR1 dependency of Pgr expression (Fox et al. 1990, Szabo et al. 2000). Again, the situation is dissimilar to that of the OVX rat because ESR2 activation does induce Pgr expression (Sánchez-Criado et al. 2004, 2006). In OVX WT mice, activation of ESR1 by $E_{2}$ induced Pgr expression in $38.4 \pm 2.6 \%$ of pituitary cells, while the average proportion of pituitary PGRpositive cells in the rat is about $10 \%$ (Sánchez-Criado et al. 2005, 2006, Garrido-Gracia et al. 2008). This difference is most likely due to the fact that in mice both gonadotropes and lactotropes express PGR (Turgeon et al. 2001). Interestingly, a decrease in the proportion of PGR-positive pituitary cells by about $15 \%$ was recorded when comparing activation of ESR1 by $E_{2}$ in OVX WT $(38.4 \pm 2.6 \%)$ and $\mathrm{KO}(23.0 \pm 4.9 \%)$ mice (present results), suggesting that activation of ESR1 in lactotropes (Turgeon et al. 2001) induces Pgr expression in OVX KO mice. Though possible, it is unlikely that $P g r$ is expressed in some gonadotropes in the absence of Esr1 expression in $\mathrm{KO}$ mice as a result of indirect activation. E-dependent gonadotrope Pgr expression is an absolute requisite for GNRH1 self-priming in the rat (Turgeon \& Waring 1994, Sánchez-Criado et al. 2006) and therefore for a full preovulatory LH surge (Fink 1988). Mouse gonadotropes also display GNRH1 self-priming and P-potentiation of GNRH1 secretion (Turgeon \& Waring 1994). PGR is necessary for E-induced signals leading to the LH surge in mice (Chappell et al. 1999). Whereas activation of ESR2 with DPN induced Pgr expression but not GNRH1 self-priming in the OVX rat (Sánchez-Criado et al. 2004), DPN had no effect on Pgr expression in OVX mice (present results). However, Pgr KO mice still exhibit GNRH1 self-priming (Turgeon \& Waring 2001) indicating that, in the mouse, PGR is not strictly necessary for amplifying the GNRH1 signal. It has been demonstrated that GNRH1 self-priming and Pgr expression have been shown to be dissociated phenomena (Sánchez-Criado et al. 2004, 2005).

As observed in rats (Sánchez-Criado et al. 2004), administration of $E_{2}$ and PPT, but not DPN, reduced serum LH levels in OVX WT and KO mice, showing that ESR1, but not ESR2, mediates E-negative feedback on LH secretion in mice (Dorling et al. 2003, present results). This suggests that the pituitary can be considered as a passive gland, depending on GNRH1 for $\mathrm{LH}$ secretion. Furthermore, the inhibitory effects of $E$ on both hypothalamic Gnrh1 mRNA levels and LH secretion are reportedly absent in global Esr1 KO mice (Wersinger et al. 1999, Dorling et al. 2003). Since GNRH1-secreting neurons do not express Esr1 (Shivers et al. 1983), the question of the supra-pituitary level at which $\mathrm{E}_{2}$ and PPT activate ESR1 arises. It seems reasonable to assume that ESR-mediated critical negative feedback is not exerted on GNRH1 neurons directly but rather transynaptically 
through modulation of interneuron afferents from several hypothalamic E-sensitive presynaptic neurons expressing Esr1 both in rats (Levine 2000, Messinis 2006, Wintermantel et al. 2006) and in mice (Yaghmaie et al. 2010).

In summary, from the parameters so far studied in the present experiments, the only role played by ESR2 on the reproductive axis of Esr1 pituitary (gonadotrope and thyrotrope)-specific $\mathrm{KO}$ mice was to revert the deleterious effects of the absence of ESR1 activity (from conception to sacrifice) on mouse gonadotrope morphology. Moreover, the absence of effects of OVX on gonadotrope size, and of ESR2 activation on Pgr expression at the time of the study, points to a mild $\mathrm{E}$ control of gonadotrope biology in the mouse. These findings confirm earlier data indicating differences in the gonadotrope biology between rats and mice (Abbot et al. 1986, Turgeon et al. 1999, 2001, Turgeon \& Waring 2001, 2006) and suggest that these two rodent species have adopted different reproductive strategies, which are further evidenced in the different response to pheromonal stimuli (Sánchez-Criado et al. 1989).

\section{Materials and Methods}

\section{Animals and general conditions}

All mice used in this study were of C57BL/6 genetic background. Forty-five-day-old $E s r^{f l / f l}$ with WT phenotype and pituitary-specific $\alpha \mathrm{GSU}$-Cre:Esr1 ${ }^{f l / f l}$ mice, referred to here as KO mice, were used (Gieske et al. 2008). KO mice were generated following a previously published strategy (Dupont et al. 2000, Gieske et al. 2008). Sibling WT mice were used as controls. KO mice thus lacked Esr1 only in gonadotropes and thyrotropes (Gieske et al. 2008). Animal handling procedures were followed in accordance with the University of Kentucky Animal Care and Use Committee.

\section{Surgery and treatments}

WT $(n=13)$ and KO mice $(n=13)$ were bilaterally OVX under isoflurane inhalation at a mean 45 days of age. Fifteen days post-OVX, mice ( $n=3 /$ group) were injected (s.c.) over three consecutive days with either $2.5 \mu \mathrm{g} \mathrm{E}_{2}$ (Sigma), $0.2 \mathrm{mg}$ of the selective ESR2 agonist DPN (Tocris, Ellisville, MO, USA; Meyers et al. 2001), or $0.2 \mathrm{mg}$ of the selective ESR1 agonist PPT (Tocris; Stauffer et al. 2000). Controls $(n=4)$ were administered $0.1 \mathrm{ml}$ olive oil by s.c. injection. The day after the third injection, animals were killed and right atrial blood was collected by cardiac puncture to determine serum LH concentrations. The anterior pituitary was dissected out and divided into two halves. One half was used for ultrastructural evaluation of gonadotrope morphology and the other for evaluation of Esr2, Lhb, and Pgr expression using IHC. The presence of uterine ballooning and vaginal smear cytology was also recorded.

\section{Preparation of pituitaries for electron microscopy}

One half of each dissected pituitary was further cut into two pieces, and tissues were fixed for $2 \mathrm{~h}$ at $4{ }^{\circ} \mathrm{C}$ in $2.5 \%$ glutaraldehyde (Ladd Research, Williston, VT, USA) in $0.1 \mathrm{M}$ cacodylate (EMS, Hatfield, PA, USA) buffer prepared on the day of use. The tissue was washed four times in $5 \%$ buffered sucrose in $0.1 \mathrm{M}$ cacodylate for $5 \mathrm{~min}$ each wash and then left in this solution for 3 days, at $4{ }^{\circ} \mathrm{C}$. Following incubation, tissue was infiltrated with $1 \%$ osmium (Ladd Research) in $0.1 \mathrm{M}$ cacodylate buffer for $1.5 \mathrm{~h}$ at $4{ }^{\circ} \mathrm{C}$ and then washed twice with $5 \%$ buffered sucrose in $0.1 \mathrm{M}$ cacodylate for 5 min each. Tissues were then dehydrated in a graded series of alcohols (50-70-80-90-100\%-absolute ethanol) for 5 min per solution. Samples were treated with propylene oxide twice for $15 \mathrm{~min}$ each and then infiltrated with $50 \%$ propylene oxide $/ 50 \%$ eponate resin $(47 \%$ LX- $112,30 \%$ DDSA, $20 \%$ NMA, and $0.013 \%$ DMP (Ladd Research)) overnight under a 60-W bulb. Vials were left uncovered to allow propylene oxide to evaporate. The following day, samples were washed twice in $100 \%$ eponate resin for $1 \mathrm{~h}$ each time. Samples were embedded in BEEM capsules in 100\% eponate resin and heated at $60{ }^{\circ} \mathrm{C}$ in an enclosed oven for 2 days. Thick sections and thin sections were prepared by the University of Kentucky Electron Microscopy and Imaging Centre. Tissue was thick sectioned $(1-2 \mu \mathrm{m})$ and stained with toluidine blue for examination under light microscopy. Selected areas were thin sectioned on a Reichert Ultracut E microtome at $60-80 \mathrm{~nm}$, mounted on copper mesh grids, and stained with uranyl acetate and lead citrate.

\section{Preparation of pituitaries for IHC}

The second half of each pituitary was placed in $10 \%$ buffered formalin for $1.5 \mathrm{~h}$. Tissues were then dehydrated in alcohol $(70 \%, 80 \%, 90 \%, 95 \%, 100 \%)$ and ethanol/xylene series (ethanol 100\%, 50\%:50\%, 30\%:70\%, 100\% xylene x 2). Each wash lasted $20 \mathrm{~min}$. Tissues were subjected to soft paraffin infiltration for $30 \mathrm{~min}$ at $60^{\circ} \mathrm{C}$, followed by two washes in hard paraffin for $30 \mathrm{~min}$ each, and then placed in paraffin blocks and allowed to cool on ice before cassettes were prepared for sectioning.

\section{Ultrastructural and morphometric examination}

Gonadotropes were identified and differentiated from other anterior pituitary cell types by the ultrastructural characteristics of the nucleus (rounded and eccentric), cytoplasm (homogeneous and moderately electron dense), secretory granules (scarce, rounded, and with varying slightly in size), and by their pituitary localization (often close to blood capillaries) (Tougard \& Tixier-Vidal 1988, Gartner \& Hiatt 2007, Garrido-Gracia et al. 2008). The other pituitary cell types were easily recognized by their ultrastructural characteristics in i) lactotropes (rounded to elongated nuclei and dark cytoplasm with secretory granules of highly heterogeneous size and shape), ii) corticotropes (displaying the lowest nuclear and cytoplasm electron density), iii) somatotropes (the most abundant cells, with large, rounded secretory granules of fairly homogeneous 
size located peripherally in the cytoplasm), and iv) thyrotropes (rounded nuclei with moderately electron dense cytoplasm and scarce secretory granules of variable uniform size but varying in distribution). The percentage of gonadotropes was evaluated under electron microscopy in two grids/mouse. Within each grid, 10 squares $\times 100 \mu \mathrm{m}$ each were analyzed $\left(200000 \mu \mathrm{m}^{2}\right.$ in total). Gonadotrope size was evaluated on the same surface area of $200000 \mu \mathrm{m}^{2} /$ mouse. Gonadotrope nuclei were delineated with a digital pen to obtain first the perimeter and later the mean diameter. Around five to seven gonadotropes were counted and measured per grid square. This examination was carried out independently by two evaluators and differences were solved by consensus after joint reassessment.

\section{IHC of pituitary PGR}

The commercial mouse monoclonal anti-human PGR receptor clone PR10A9 (Immunotech, Marseille, France), diluted 1:15 000, and the avidin-biotin-peroxidase complex (ABC) IHC technique were used as described previously (Sánchez-Criado et al. 2004). Three consecutive tissue sections per case were immunostained. Images were captured $(\times 40$ microscope lens) from four randomly selected neighboring, non-overlapping fields of each immunostained tissue section. The number of PGR-positive and -negative cells was counted with a digital pen tablet (Volito2; Wacom Europe $\mathrm{GmbH}$, Krefeld, Germany). The percentage of PGR-positive cells was calculated using Image-Pro Plus 4.5. A minimum of 1000 anterior pituitary cells were counted per tissue section (3000 per case).

\section{Co-localization of ESR2 and Lhb in pituitary cells}

For the simultaneous IHC co-localization of ESR2 and LHB in a single tissue section, individual immunostainings with each antibody were performed consecutively. Polyclonal rabbit anti-LHB (AbDSerotec, Dusseldorf, Germany), diluted 1:200, was incubated for $18 \mathrm{~h}$ at $4{ }^{\circ} \mathrm{C}$ after three 10 min washes in PBS; the ABC method (Vector Laboratories, Burlingame, CA, USA) was applied following manufacturer's recommendations and the immune reaction was developed with the chromogen DAB. Next, tissue sections were subjected to high-temperature antigen retrieval by incubation with $0.01 \mathrm{M}$ citrate buffer, $\mathrm{pH}$ 6.0 , at $95{ }^{\circ} \mathrm{C}$ for $3 \mathrm{~min}$ in a water bath for ESR2 detection. After cooling down at room temperature for $20 \mathrm{~min}$, endogenous peroxidase activity was blocked with $3 \%$ hydrogen peroxidase in methanol for $30 \mathrm{~min}$ at room temperature. Polyclonal rabbit anti-human ESR2 antibody (Upstate Biotechnology-Millipore, Billerica, MA, USA), diluted 1:40, was incubated for $18 \mathrm{~h}$ at $4{ }^{\circ} \mathrm{C}$. After three $10 \mathrm{~min}$ washes in PBS, the $\mathrm{ABC}$ method was applied following manufacturer's recommendations. This immune reaction was developed with the chromogen Novared (Vector Laboratories). Nuclei were counterstained with Harris hematoxylin.

\section{Measurement of serum $\mathbf{L H}$ concentrations}

IRMA of serum LH levels was performed by the University of Virginia Center for Research in Reproduction Ligand Assay and Analysis core (NICHD (SCCPRR) Grant U54-HD28934,
University of Virginia, VA, USA). All samples were tested in the same assay. The intra-assay coefficient of variation was $3.1 \%$ and assay sensitivity was $0.07 \mathrm{ng} / \mathrm{ml}$. Serum LH concentrations were expressed as nanogram per milliliter.

\section{Statistical analysis}

All data had normal distribution and homogeneous variance. In accordance, statistical analysis was performed by two-way ANOVA to test for significant differences among groups (Hardyck \& Petrinovich 1976). Where significant differences existed, ANOVA was followed by the Student-Newman-Keuls multiple range test. Significance was considered at the 0.05 level.

\section{Declaration of interest}

The authors declare that there is no conflict of interest that could be perceived as prejudicing the impartiality of the research reported.

\section{Funding}

This work was subsidized by grants: i) BFU2008-00480 and AGL2011-25553 from DGPTC, Ministerio de Ciencia e Innovación, Spain, ii) P07-CVI-02559 from CICE, Junta de Andalucia, Spain, and iii) RO1HDO52694 and P20RR15592 (to $\mathrm{C} \mathrm{Ko}$ ) from the National Institute of Health, USA.

\section{Acknowledgements}

The sabbatical leave of J E Sánchez-Criado in the Center of Excellence in Reproductive Sciences, University of Kentucky, Lexington, Kentucky, was sponsored by the Junta de Andalucia (Spain).

\section{References}

Abbot SD, Naik SI \& Clayton RN 1986 Dissociation between pituitary $\mathrm{GnRH}$ binding sites and $\mathrm{LH}$ response to $\mathrm{GnRH}$ in vitro. Molecular and Cellular Endocrinology 48 191-197. (doi:10.1016/0303-7207(86) 90041-9)

Alonso R, Marín F, González M, Guelmes P, Bellido C, Hernández G, Marín R, Díaz M \& Sánchez-Criado J 2006 The hypothalamus-pituitaryovarian axis as a model system for the study of SERM effects: an overview of experimental and clinical study. In In Selective Estrogen Receptor Modulators New Brand of Multitargeted Drugs, pp 103-139. Eds A Cano, J Calaf i Alsina \& JL Dueñas-Diez. Berlin: Springer-Verlag.

Chappell PE, Schneider JS, Kim P, Xu M, Lydon JP, O'Malley BW \& Levine JE 1999 Absence of gonadotropin surges and gonadotropin-releasing hormone self-priming in ovariectomized $(\mathrm{OVX})$, estrogen $\left(\mathrm{E}_{2}\right)$-treated, progesterone receptor knockout (PRKO) mice. Endocrinology 140 3653-3658. (doi:10.1210/en.140.8.3653)

Dorling AA, Todman MG, Korach KS \& Herbison AE 2003 Critical role for estrogen receptor $\alpha$ in negative feedback regulation of gonadotropinreleasing hormone mRNA expression in the female mouse. Neuroendocrinology 78 204-209. (doi:10.1159/000073703)

Dupont S, Krust A, Gansmuller A, Dierich A, Chambon P \& Mark M 2000 Effect of single and compound knockouts of estrogen receptors $\alpha$ (ER $\alpha)$ and $\beta(E R \beta)$ on mouse reproductive phenotypes. Development 127 4277-4291. 
Fink G 1988 Gonadotropin secretion and its control. In The Physiology of Reproduction, pp 1349-1377. Eds E Knobil \& J Neill. New York, NY: Raven Press.

Fink G 2000 Neuroendocrine regulation of pituitary function. In Neuroendocrinology in Physiology and Medicine, pp 107-183. Eds PM Conn \& ME Freeman. Totowa, NJ: Humana Press.

Fox SR, Harlan RE, Shivers BD \& Pfaff DW 1990 Chemical characterization of neuroendocrine targets for progesterone in the female rat brain and pituitary. Neuroendocrinology 51 276-283. (doi:10.1159/000125350)

Frasor J, Barnett DH, Danes JM, Hess R, Parlow AF \& Katzenellenbogen BS 2003 Response-specific and ligand dose-dependent modulation of estrogen receptor (ER) $\alpha$ activity by ER $\beta$ in the uterus. Endocrinology 144 3159-3166. (doi:10.1210/en.2002-0143)

Garner LL \& Blake CA 1981 Ultrastructural, immunocytochemical study of the $\mathrm{LH}$ secreting cell of the rat anterior pituitary gland: changes occurring after ovariectomy. Biology of Reproduction 24 461-474. (doi:10.1095/ biolreprod24.2.461)

Garrido-Gracia JC, Gordon A, Bellido C, Aguilar R, Barranco I, Millan Y, de Las Mulas JM \& Sánchez-Criado JE 2007 The integrated action of oestrogen receptor isoforms and sites with progesterone receptor in the gonadotrope modulates LH secretion: evidence from tamoxifen-treated ovariectomized rats. Journal of Endocrinology 193 107-119. (doi:10. 1677/JOE-06-0214)

Garrido-Gracia JC, Gordon A, Aguilar R, Monterde JG, Blanco A, Martin de Las Mulas J \& Sánchez-Criado JE 2008 Morphological effects of oestradiol-17 $\beta$, and selective oestrogen receptor $\alpha$ and $\beta$ agonists on luteinising hormone-secreting cells in tamoxifen-treated ovariectomised rats. Histology and Histopathology 23 1453-1463.

Gartner LP \& Hiatt JL 2007 Endocrine system. In Color Textbook of Histology, pp 303-326. Philadelphia: Saunders Elsevier.

Gieske MC, Kim HJ, Legan SJ, Koo Y, Krust A, Chambon P \& Ko C 2008 Pituitary gonadotroph estrogen receptor- $\alpha$ is necessary for fertility in females. Endocrinology 149 20-27. (doi:10.1210/en.2007-1084)

Goodman RL \& Knobil E 1981 The sites of action of ovarian steroids in the regulation of LH secretion. Neuroendocrinology 32 57-63. (doi:10. 1159/000123130)

Gordon A, Aguilar R, Garrido-Gracia JC, Guil-Luna S, SánchezCespedes R, Millan Y, Martín de las Mulas J \& Sánchez-Criado JE 2009 Activation of estrogen receptor- $\alpha$ induces gonadotroph progesterone receptor expression and action differently in young and middle-aged ovariectomized rats. Human Reproduction 24 2618-2628. (doi:10.1093/humrep/dep237)

Hardyck CD \& Petrinovich LF 1976 Introduction to Statistics for the Behavioral Sciences. Philadelphia, PA: W.B. Saunders Company.

Harris HA, Katzenellenbogen JA \& Katzenellenbogen BS 2002 Characterization of the biological roles of the estrogen receptors, $E R \alpha$ and $E R \beta$, in estrogen target tissues in vivo through the use of an ER $\alpha$-selective ligand. Endocrinology 143 4172-4177. (doi:10.1210/en.2002-220403)

Hewitt SC \& Korach KS 2003 Oestrogen receptor knockout mice: roles for oestrogen receptors $\alpha$ and $\beta$ in reproductive tissues. Reproduction 125 143-149. (doi:10.1530/rep.0.1250143)

Imamov O, Shim GJ, Warner M \& Gustafsson JA 2005 Estrogen receptor $\beta$ in health and disease. Biology of Reproduction 73 866-871. (doi:10. 1095/biolreprod.105.043497)

Kim HJ, Gieske MC, Trudgen KL, Hudgins-Spivey S, Kim BG, Krust A, Chambon P, Jeong JW, Blalock E \& Ko C 2011 Identification of estradiol/ER $\alpha$-regulated genes in the mouse pituitary. Journal of Endocrinology 210 309-321. (doi:10.1530/JOE-11-0098)

Koehler KF, Helguero LA, Haldosen LA, Warner M \& Gustafsson JA 2005 Reflections on the discovery and significance of estrogen receptor $\beta$. Endocrine Reviews 26 465-478. (doi:10.1210/er.2004-0027)

Legan SJ \& Tsai H-W 2003 Oestrogen receptor- $\alpha$ and - $\beta$ immunoreactivity in gonadotropin-releasing hormone neurones after ovariectomy and chronic exposure to oestradiol. Journal of Neuroendocrinology 15 1164-1170. (doi:10.1111/j.1365-2826.2003.01115.x)

Levine JE 2000 The hypothalamus as a major integrating center. In Neuroendocrinology in Physiology and Medicine, pp 79-93. Eds PM Conn \& ME Freeman. Totowa, NJ: Humana Press, Inc.

Messinis IE 2006 Ovarian feedback, mechanism of action and possible clinical implications. Human Reproduction Update 12 557-571. (doi:10.1093/humupd/dml020)
Meyers MJ, Sun J, Carlson KE, Marriner GA, Katzenellenbogen BS \& Katzenellenbogen JA 2001 Estrogen receptor- $\beta$ potency-selective ligands: structure-activity relationship studies of diarylpropionitriles and their acetylene and polar analogues. Journal of Medicinal Chemistry 44 4230-4251. (doi:10.1021/jm010254a)

Parker MG 1995 Structure and function of estrogen receptors. Vitamins and Hormones 51 267-287.

Pettersson K \& Gustafsson JA 2001 Role of estrogen receptor $\beta$ in estrogen action. Annual Review of Physiology 63 165-192. (doi:10.1146/ annurev.physiol.63.1.165)

Sánchez-Criado JE, Mora OA \& Gallego A 1989 Structure and function of the vomeronasal system. In Progress in Sensory Physiology 9, pp 193-222. Ed. D Ottoson. Heidelberg, Germany: Springer-Verlag.

Sánchez-Criado JE, Martín de las Mulas J, Bellido C, Tena-Sempere M, Aguilar R \& Blanco A 2004 Biological role of pituitary estrogen receptors $E R \alpha$ and $E R \beta$ on progesterone receptor expression and action and on gonadotropin and prolactin secretion in the rat. Neuroendocrinology 79 247-258. (doi:10.1159/000079100)

Sánchez-Criado JE, Martín de las Mulas J, Bellido C, Aguilar R \& GarridoGracia JC 2005 Gonadotrope oestrogen receptor- $\alpha$ and $-\beta$ and progesterone receptor immunoreactivity after ovariectomy and exposure to oestradiol benzoate, tamoxifen or raloxifene in the rat: correlation with LH secretion. Journal of Endocrinology 184 59-68. (doi:10.1677/ joe.1.05748)

Sánchez-Criado JE, de Las Mulas JM, Bellido C, Navarro VM, Aguilar R, Garrido-Gracia JC, Malagon MM, Tena-Sempere M \& Blanco A 2006 Gonadotropin-secreting cells in ovariectomized rats treated with different oestrogen receptor ligands: a modulatory role for ER $\beta$ in the gonadotrope? Journal of Endocrinology 188 167-177. (doi:10.1677/joe. 1.06377)

Schwartz NB 2000 Neuroendocrine regulation of reproductive cyclicity. In Neuroendocrinology in Physiology and Medicine, pp 135-145. Eds PM Conn \& ME Freeman. Totowa, NJ: Humana Press, Inc.

Shivers BD, Harlan RE, Morrell JI \& Pfaff DW 1983 Absence of oestradiol concentration in cell nuclei of LHRH-immunoreactive neurones. Nature 304 345-347. (doi:10.1038/304345a0)

Singh SP, Wolfe A, Ng Y, DiVall SA, Buggs C, Levine JE, Wondisford FE \& Radovick S 2009 Impaired estrogen feedback and infertility in female mice with pituitary-specific deletion of estrogen receptor $\alpha$ (ESR1). Biology of Reproduction 81 488-496. (doi:10.1095/biolreprod.108. 075259)

Smith PF, Frawley LS \& Neill JD 1984 Detection of LH release from individual pituitary cells by the reverse hemolytic plaque assay: estrogen increases the fraction of gonadotropes responding to $\mathrm{GnRH}$. Endocrinology 115 2484-2486. (doi:10.1210/endo-115-6-2484)

Stauffer SR, Coletta CJ, Tedesco R, Nishiguchi G, Carlson K, Sun J, Katzenellenbogen BS \& Katzenellenbogen JA 2000 Pyrazole ligands: structure-affinity/activity relationships and estrogen receptor- $\alpha$-selective agonists. Journal of Medicinal Chemistry 43 4934-4947. (doi:10.1021/ jm000170m)

Sugiyama N, Barros RP, Warner M \& Gustafsson JA 2010 ER $\beta$ : recent understanding of estrogen signaling. Trends in Endocrinology and Metabolism 21 545-552. (doi:10.1016/j.tem.2010.05.001)

Sun J, Meyers MJ, Fink BE, Rajendran R, Katzenellenbogen JA \& Katzenellenbogen BS 1999 Novel ligands that function as selective estrogens or antiestrogens for estrogen receptor- $\alpha$ or estrogen receptor- $\beta$. Endocrinology 140 800-804. (doi:10.1210/en.140.2.800)

Szabo M, Kilen SM, Nho SJ \& Schwartz NB 2000 Progesterone receptor A and $B$ messenger ribonucleic acid levels in the anterior pituitary of rats are regulated by estrogen. Biology of Reproduction 62 95-102. (doi:10. 1095/biolreprod62.1.95)

Tougard CL \& Tixier-Vidal A 1988 Lactotropes and gonadotropes. In The Physiology of Reproduction, pp 1305-1333. Eds E Knobil \& J Neill. New York: Raven Press.

Turgeon JL \& Waring DW 1994 Activation of the progesterone receptor by the gonadotropin-releasing hormone self-priming signaling pathway. Molecular Endocrinology 8 860-869. (doi:10.1210/me.8.7.860)

Turgeon JL \& Waring DW 2001 Luteinizing hormone secretion from wild-type and progesterone receptor knockout mouse anterior pituitary cells. Endocrinology 142 3108-3115. (doi:10.1210/en.142. 7.3108) 
Turgeon JL \& Waring DW 2006 Differential expression and regulation of progesterone receptor isoforms in rat and mouse pituitary cells and LbetaT2 gonadotropes. Journal of Endocrinology 190 837-846. (doi:10. 1677/joe.1.06923)

Turgeon JL, Van Patten SM, Shyamala G \& Waring DW 1999 Steroid regulation of progesterone receptor expression in cultured rat gonadotropes. Endocrinology 140 2318-2325. (doi:10.1210/en.140.5.2318)

Turgeon JL, Shymala G \& Waring DW 2001 Progesterone receptor localization and anterior pituitary cell populations in vitro in ovariectomized wild-type and PR-knockout mice. Endocrinology 142 4479-4485. (doi:10.1210/en.142.10.4479)

Wersinger SR, Haisenleder DJ, Lubahn DB \& Rissman EF 1999 Steroid feedback on gonadotropin release and pituitary gonadotropin subunit mRNA in mice lacking a functional estrogen receptor $\alpha$. Endocrine $\mathbf{1 1}$ 137-143. (doi:10.1385/ENDO:11:2:137)

Wilson ME, Price RH \& Handa RJ 1998 Estrogen receptor- $\beta$ messenger ribonucleic acid expression in the pituitary gland. Endocrinology 139 5151-5156. (doi:10.1210/en.139.12.5151)
Wintermantel TM, Campbell RE, Porteous R, Bock D, Grone HJ, Todman MG, Korach KS, Greiner E, Perez CA, Schutz G et al. 2006 Definition of estrogen receptor pathway critical for estrogen positive feedback to gonadotropin-releasing hormone neurons and fertility. Neuron 52 271-280. (doi:10.1016/j.neuron.2006.07.023)

Yaghmaie F, Saeed O, Garan SA, Voelker MA, Sternberg H \& Timiras PS 2010 Estrogen receptor- $\alpha$ immunoreactivity in the arcuate hypothalamus of young and middle-aged female mice. Neuroendocrinology Letters 31 $56-62$.

Received 17 June 2011

First decision 20 July 2011

Revised manuscript received 6 February 2012

Accepted 21 February 2012 